\title{
Assessing the Influence of Proportions Between Amount of Vegetables Immersed and Volume of Water To Inactivate Salmonella in Minimally Processed Lettuce and Carrot, Mimicking Disinfection Practices Employed by Brazilian Processing Plants
}

\author{
Daniele Fernanda Maffei (I), Rubia de Souza Olivo (I), Katia Leani \\ Oliveira de Souza Silva (I), Anderson de Souza Sant'Ana (II), \\ Bernadette Dora Gombossy de Melo Franco $(\mathrm{I}, \mathrm{I})$
}

(I) USP - University of Sao Paulo (Av. Prof. Lineu Prestes 580, 05508-000, Sao Paulo, SP), (II) UNICAMP - State University of Campinas (Rua Monteiro Lobato, 80 13083-862, Campinas, SP)

\section{Resumo}

The proportion between amount of vegetables immersed and volume of water used during the disinfection step of minimally processed vegetables (MPV) is a factor that can affect the efficacy of disinfection process and consequently the quality and safety of the final product. This study aimed at assessing the influence of proportion between amount of vegetables immersed and volume of water on inactivation of Salmonella during the disinfection step of minimally processed lettuce and carrot, mimicking practices employed by MPV processing plants in Sao Paulo, Brazil. Minimally processed lettuce or carrot $(1 \mathrm{Kg})$ was spiked with Salmonella (6 $\log \mathrm{CFU} / \mathrm{mL}$ ) through immersion in experimentally contaminated water $\left(4 \mathrm{~L}\right.$ at $25^{\circ} \mathrm{C}$ ) for $30 \mathrm{~min}$, and then transferred to recipients containing water with organic chlorine $\left(250 \mathrm{mg} / \mathrm{L}\right.$ at $25^{\circ} \mathrm{C}$ and $\left.\mathrm{pH} 7.0\right)$. The volumes of water tested to disinfect $1 \mathrm{Kg}$ of lettuce were 8, 16, 23 and $28 \mathrm{~L}$, while for disinfection of $1 \mathrm{Kg}$ of carrot were tested 1, 6 and $12 \mathrm{~L}$ of water. These values corresponded to the proportions employed by Brazilian processing plants during disinfection step of MPV. The disinfection of minimally processed lettuce caused a reduction of $1.8,1.9,1.9$ and $2.0 \log \mathrm{CFU} / \mathrm{g}$

\footnotetext{
Referência:

Daniele Fernanda Maffei, Rubia de Souza Olivo, Katia Leani Oliveira de Souza Silva, Anderson de Souza Sant'Ana, Bernadette Dora Gombossy de Melo Franco. Assessing the Influence of Proportions Between Amount of Vegetables Immersed and Volume of Water To Inactivate Salmonella in Minimally Processed Lettuce and Carrot, Mimicking Disinfection Practices Employed by Brazilian Processing Plants. In: Anais do 12 Congresso Latinoamericano de Microbiologia e Higiene de Alimentos - MICROAL 2014 [= Blucher Food Science Proceedings, num.1, vol.1]. São Paulo: Editora Blucher, 2014.

DOI 10.5151/foodsci-microal-182
} 
when the volumes of $8,16,23$ and $28 \mathrm{~L}$ of water, respectively, were used. On the other hand, the disinfection of minimally processed carrot caused a reduction of 2.1, 2.1 and $2.4 \log \mathrm{CFU} / \mathrm{g}$ when the volumes of 1,6 and $12 \mathrm{~L}$ of water, respectively, were used. These values were not statically different (ANOVA test; $p>0.05$ ), which indicates that under the same water conditions $\left(250 \mathrm{mg} / \mathrm{L}\right.$ at $25^{\circ} \mathrm{C}$ and $\left.\mathrm{pH} 7.0\right)$, the proportions tested not differed on the inactivation of Salmonella. Nevertheless, the disinfection process was most efficient to reduce Salmonella counts in minimally processed carrot than in minimally processed lettuce, which can be due the difference on the vegetable surface. The different proportions between amount of vegetables immersed and volume of water employed by Brazilian processing plants during the disinfection step of MPV not showed influence on the inactivation of Salmonella when carried out under the same water conditions.

Palavras-Chave: Disinfection practices, Minimally processed vegetables, Salmonella

Agência de Fomento: Fundação de Amparo à Pesquisa do Estado de São Paulo - FAPESP (Process 2012/03471-1) 